supplied the samples. We also thank the nursing and records staff in each hospital and our technicians for their help.

Requests for reprints should be addressed to: Dr C M Gosden, MRC Clinical and Population Cytogenetics Unit, Western General Hospital, Edinburgh.

\section{References}

1 Brock DJH, Sutcliffe RG. Alphafetoprotein in the antenatal diagnosis of anencephaly and spina bifida. Lancet 1972 ;ii:197-9.

2 Smith AD, Wald NJ, Cuckle HS, Stirrat GM, Bobrow M, Langercrantz $\mathrm{H}$. Amniotic fluid acetylcholinesterase and neural tube defects. Lancet $1979 ; \mathrm{i}: 880-1$.

${ }^{3}$ Brock DJH, Scrimgeour JB, Steven JD, Barron L, Watt M. Maternal plasma screening for fetal neural tube defects. Br $\mathcal{F}$ Obstet Gynaecol 1978;85:575-81.

${ }^{4}$ Buckton KE, O'Riordan ML, Ratcliffe SG, et al. A G-banded study of chromosomes in liveborn infants. Ann Hum Genet 1980;43:227-39.

${ }^{5}$ Gosden CM, Wright MO, Paterson WG, Grant KA. Clinical details, cytogenetic studies and cellular physiology of a $69, \mathrm{XXX}$ fetus with comments on the biological effect of triploidy in man. F Med Genet 1976; 13:371-80.

${ }^{6}$ Gosden CM, Brock DJH. Morphology of rapidly adhering amniotic fluid cells as an aid to the diagnosis of neural tube defects. Lancet 1977 ; : 919-22.

${ }^{7}$ Gosden CM, Brock DJH. Combined use of alphafetoprotein and amniotic fluid cell morphology in early prenatal diagnosis of fetal abnormalities. f Med Genet 1978;15:262-70.

${ }^{8}$ Gosden CM, Brock DJH. Amniotic fluid cell morphology in early antenatal prediction of abortion and low birth weight. $\mathrm{Br}$ Med $\mathcal{F} 1978$;ii 1186-9.

๑ Anderson I. Fetal calf serum drought hits cell culture laboratories. Nature $1980 ; 285$ : 63.

${ }^{10}$ Milunsky A, Atkins L. Prenatal diagnosis of chromosomal mosaicism. 7 Pediatr 1976;88:365-6.

11 Peakman DC, Moreton MF, Corn BJ, Robinson A. Chromosomal mosaicism in amniotic fluid cell cultures. Am $\mathcal{F}$ Hum Genet 1979;31 : 149-55.
${ }^{12}$ Seller MJ, Creasy MR, Alberman E. Alpha-fetoprotein in amniotic fluids from spontaneous abortions. Br Med f 1974; ;i :624-5.

${ }^{13}$ Chemke J, Nisani R, Kassif R, Lancet M, Beiser R,'Hurwitz N. Prenatal diagnosis of severe congenital malformations with elevated amniotic fluid alpha-fetoprotein. Clin Genet 1979;15:351-5.

${ }^{14}$ Fitzsimmons JS, Filshie GM, Hill AS, Kime R. Antenatal diagnosis of trisomy 13 with unexpected increase in alpha-fetoprotein. $\mathcal{F}$ Med Genet $1976 ; 13: 400-12$.

${ }^{15}$ Seller MJ. Raised amniotic fluid alpha-fetoprotein in Turner syndrome. Lancet 1976; : 807 .

16 Wald NJ, Barker S, Cuckle H, Brock DJH, Stirrat GM. Maternal serum AFP and spontaneous abortion. Br F Obstet Gynaecol 1977;84:357-62.

${ }^{17}$ Brock DJH, Barron L, Duncan P, Scrimgeour JB, Watt M. Significance of elevated mid trimester maternal plasma-alpha-fetoprotein values. Lancet 1979;i:1281-2.

${ }^{18}$ Milunsky A, ed. Prenatal diagnosis of neural tube defects. In: Genetic disorders and the fetus. New York: Plenum Press, 1979:379-430.

${ }^{19}$ Medical Research Council Working Party on Amniocentesis. An assessment of the hazards of amniocentesis. Br f Obstet Gynaecol 1978;85, suppl $2: 1-41$.

${ }^{20}$ Hook EB, Hamerton JL. The frequency of chromosome abnormalities detected in consecutive newborn studies. In: Hook EB, Porter IH, eds. Population cytogenetics. New York: Academic Press, 1977:63-79.

${ }^{21}$ Anonymous. What is to be done with the XYY fetus ? Br Med $\mathcal{F} 1979$; 1519-20.

${ }^{22}$ Child DP. What is to be done with the XYY fetus ? Br Med $\mathcal{F} 1979$;ii: 54.

${ }^{23}$ Farrant W, Hulten M. What is to be done with the XYY fetus ? Br Med F 1979 ;ii:131.

${ }^{24}$ Ratcliffe SG, Axworthy DG. What is to be done with XYY fetus? Br Med F 1979 ;ii 672 .

${ }^{25}$ Bennett MJ, Blau K, Johnston RD, Chamberlain GVP. Some problems of alpha-fetoprotein screening. Lancet 1978 ;ii:1296-7.

${ }^{26}$ Ferguson-Smith MA, Gibson AAM, Whitfield CR, Ratcliffe JG. Amniocentesis and the alpha-fetoprotein screening programme. Lancet 1979; i:34-40.

${ }^{27}$ Brock DJH, Gosden C. Serum alpha-fetoprotein screening and risk of amniocentesis. Lancet 1979;ii:206.

${ }^{28}$ Milunsky A, ed. Prenatal diagnosis of chromosomal disorders. In: Genetic disorders and the fetus. New York: Plenum Press, 1979:93-156.

\title{
Natural history of autoimmune thyroiditis
}

\author{
W M G TUNBRIDGE, MARY BREWIS, JOYCE M FRENCH, D APPLETON, T BIRD, F CLARK, \\ D C EVERED, J GRIMLEY EVANS, R HALL，P SMITH，J STEPHENSON, E YOUNG
}

\begin{abstract}
One hundred and sixty-three asymptomatic people with thyroid antibodies or raised serum thyrotrophin (TSH) concentrations, or both, and 209 age-matched and sexmatched controls without either marker of thyroid disorder were followed up for four years to determine the natural history of autoimmune thyroiditis. Mildly raised TSH concentrations alone and the presence of thyroid antibodies alone did not significantly increase
\end{abstract}

Newcastle upon Tyne University Hospitals, Newcastle upon Tyne W M G TUNBRIDGE, MD, FRCP, consultant physician

MARY BREWIS, MD, senior research associate

JOYCE M FRENCH, BSC, research associate

D APPLETON, PHD, senior lecturer in medical statistics

T BIRD, MD FCPATH, consultant pathologist

F CLARK, FRCP, consultant physician

D C EVERED, MD, FRCP, consultant physician (present appointment: director, Ciba Foundation)

J GRIMLEY EVANS, MD, FRCP, professor of medicine (geriatrics)

R HALL, MD, FRCP, professor of medicine (present appointment : professor of medicine, Welsh National School of Medicine, Cardiff)

P SMITH, PHD, hospital biochemist

J STEPHENSON, FIMLS, senior chief medical laboratory scientific officer

E YOUNG, FRCP, consultant physician the risk of developing overt hypothyroidism during the four years compared with the controls. Overt hypothyroidism developed at the rate of $5 \%$ a year in women who initially had both raised TSH concentrations and thyroid antibodies.

Prophylactic treatment with thyroxine may be justified in women found to have both markers of impending thyroid failure. The cost effectiveness of screening the adult population remains to be evaluated.

\section{Introduction}

Overt hypothyroidism is a common condition that develops insidiously and is often not recognised until it has been present for a considerable time. The clinical features are not specific, and the diagnosis is often made only when there is a full range of the symptoms and signs that are associated with myxoedema. In overt primary hypothyroidism serum thyrotrophin (TSH) concentrations are invariably raised, thyroxine concentrations are depressed, and thyroid antibodies are usually present, reflecting the underlying autoimmune process that is believed to be the usual cause. Raised TSH concentrations and thyroid antibodies are present before the clinical features become apparent and may be used to identify people at risk of progression to overt hypothyroidism. 
The prevalence of these markers of thyroid dysfunction has been reported, ${ }^{1-3}$ but little is known of the incidence of overt hypothyroidism in people who possess one or other or both markers. Necropsy studies of people dying from various causes have shown that lymphocytic infiltration of the thyroid (which correlates well with the presence of thyroid antibodies) is present in many such people who have lived a normal span and never had clinical evidence of thyroid disease during life. ${ }^{4-6}$ Nevertheless, possibly an appreciable proportion of people with evidence of autoimmune thyroiditis will develop overt hypothyroidism and the earliest marker may be a raised serum TSH concentration. The present study was undertaken to determine the course of autoimmune thyroiditis and the incidence of overt hypothyroidism in the community.

\section{Methods}

The original survey was conducted in the community of Whickham near Newcastle upon Tyne.' All people identified in the original survey as having either thyroid antibodies or raised TSH concentrations, or both, in the absence of overt or treated thyroid disease, together with age-matched and sex-matched controls without either marker of thyroid disorder, were selected for follow-up. Participants were reassessed at two-year intervals over four years. since seen in the original survey. Affirmative replies were checked against family practitioner and hospital records. Practitioner records were also checked for those who failed to reply. Certified causes of death were ascertained for all people who had died during the followup. Data from completed questionnaires were transferred to punch cards, which were then processed using the Statistical Package for the Social Sciences. ${ }^{16}$

\section{Results}

Two hundred and fifty-two people with thyroid antibodies or raised TSH concentrations, or both, and 297 age-matched and sex-matched controls without either marker of thyroid disorder were selected for the follow-up study. Patients with one or both markers who had received antithyroid treatment were not included in the study. The proportion of women to men was roughly 3:1, reflecting the predominance of autoimmune thyroiditis in the former. The mean $( \pm S D)$ age at selection for all subjects studied was $49+15$ years.

Three-quarters of those selected were seen for reassessment after two years and two-thirds after four years. At four years the proportions of subjects who had died $(5.6 \%)$, moved out of the area $(8.2 \%)$, or refused to participate $(18.4 \%)$ were similar in the subjects with markers and controls (table I). The age and sex distributions of the 372 people remaining in the study at the end of the four years were similar in the controls and people with markers. The marker group

TABLE I-Numbers of people selected for study and outcome of follow-up after two and four years

\begin{tabular}{|c|c|c|c|c|c|c|c|}
\hline & \multicolumn{3}{|c|}{ Controls } & \multicolumn{3}{|c|}{ People with markers } & \multirow[b]{2}{*}{$\begin{array}{l}\text { Total }(\%) \\
(n=549)\end{array}$} \\
\hline & $\underset{(\mathrm{n}=\mathbf{8 1})}{\operatorname{Men}}$ & $\begin{array}{c}\text { Women } \\
(\mathrm{n}=216)\end{array}$ & $\begin{array}{l}\text { Total(\%) } \\
(n=297)\end{array}$ & $\begin{array}{c}\text { Men } \\
(n=61)\end{array}$ & $\begin{array}{c}\text { Women } \\
(\mathrm{n}=191)\end{array}$ & $\begin{array}{l}\text { Total(\%) } \\
(n=252)\end{array}$ & \\
\hline \multicolumn{8}{|c|}{ Two-year follow-up } \\
\hline \multirow{2}{*}{$\begin{array}{l}\text { Seen } \\
\text { Not seen: } \\
\text { Died } \\
\text { Moved } \\
\text { Refused }\end{array}$} & 61 & 176 & $237(80)$ & 45 & 143 & $188(75)$ & $425(77)$ \\
\hline & $\begin{array}{l}8 \\
5 \\
7\end{array}$ & $\begin{array}{r}4 \\
3 \\
33\end{array}$ & $\begin{aligned} 12 & (4) \\
8 & (3) \\
40 & (13)\end{aligned}$ & $\begin{array}{l}3 \\
8 \\
5\end{array}$ & $\begin{array}{r}8 \\
9 \\
31\end{array}$ & $\begin{array}{l}11(4) \\
17(7) \\
36(14)\end{array}$ & $\begin{array}{l}23(4) \\
25(5) \\
76(14)\end{array}$ \\
\hline \multicolumn{8}{|c|}{ Four-year follow-up } \\
\hline \multirow{2}{*}{$\begin{array}{l}\text { Seen } \\
\text { Not seen: } \\
\text { Died } \\
\text { Moved } \\
\text { Refused }\end{array}$} & 51 & 158 & $209(70)$ & 39 & 124 & $163(65)$ & $372(68)$ \\
\hline & $\begin{array}{l}2 \\
6 \\
2\end{array}$ & $\begin{array}{l}3 \\
6 \\
9\end{array}$ & $\begin{array}{l}5(2) \\
12(4) \\
11(4)\end{array}$ & $\begin{array}{l}1 \\
1 \\
4\end{array}$ & $\begin{array}{r}2 \\
7 \\
10\end{array}$ & $\begin{array}{r}3(1) \\
8(3) \\
14(6)\end{array}$ & $\begin{array}{r}8(1) \\
20(4) \\
25(5)\end{array}$ \\
\hline
\end{tabular}

The reassessment consisted of a symptomatic inquiry and examination particularly for evidence of thyroid disease and vascular disease. A standard questionnaire for chest pain on effort and possible myocardial infarction 7 was repeated, and blood pressure recorded using a random zero sphygmomanometer ${ }^{8}$ with the patient recumbent after 12 -lead electrocardiography. A fasting blood sample was taken for the following measurements: serum concentrations of TSH, ${ }^{9}$ thyroxine (Thyopac-4, Amersham), and triiodothyronine ${ }^{10}$; triiodothyronine Sephadex uptake (Thyopac-3, Amersham) used in conjunction with the thyroxine concentration to derive a free thyroxine index, ${ }^{11}$ thyroglobulin antibodies, ${ }^{12}$ and thyroid cytoplasmic (microsomal) antibodies by immunofluorescence ${ }^{13}$ and microsomal haemagglutination techniques $^{14}$; antibodies to gastric parietal cells, smooth muscle, mitochondria, and antinuclear factor measured by an immunofluorescence technique; and serum concentrations of cholesterol (Technicon method file $\mathrm{N} 24 \mathrm{a}$ ), triglyceride, ${ }^{15}$ and glucose (oxidase method, Autoanalyser).

Serum from each subject was divided, half being used immediately for the above investigations and the remainder stored at $-20^{\circ} \mathrm{C}$ until the end of the four-year study. Basal samples and those obtained at two-year and four-year follow-up were then retested in the same assay.

Thyroglobulin antibodies were scored as present at a titre of $1 / 20$ or more and microsomal antibodies at a titre of $1 / 100$ or more; serum TSH concentrations were defined as raised when greater than 6 $\mathrm{mU} / 1$ in the original survey.

A postal questionnaire was sent after four years to all the other participants in the original Whickham survey, who had not been selected for special follow-up as above. This questionnaire asked if the person had developed any thyroid, heart, or blood pressure troubles was subdivided into: (a) those with antibodies and normal initial TSH concentrations; $(b)$ those with raised initial TSH concentrations but no antibodies; and $(c)$ those with both antibodies and raised initial TSH concentrations (table II).

TABLE II-Numbers of people who completed four years of follow-up

\begin{tabular}{lcc}
\hline & Men & Women \\
\hline Controls & 51 & 158 \\
People with markers: & 39 & 124 \\
Antibodies alone & 20 & 67 \\
Raised TSH alone & 9 & 27 \\
Antibodies and raised TSH & 10 & 30 \\
\hline & 90 & 282
\end{tabular}

The postal questionnaire was sent to 2163 people without raised TSH concentrations or thyroid antibodies seen in the original survey, and to 76 people who had declined to participate in the special followup study. Replies were received from 1748 (78\%), and information on the remaining $491(22 \%$ ) was sought from practitioners' records; 142 $(6 \%)$ had died and $205(9 \%)$ had moved from the area.

Causes of death for all subjects followed up in any way were ascertained from death certificates and were cardiovascular disease $(2 \cdot 7 \%)$, cerebrovascular disease $(1 \cdot 6 \%)$, and miscellaneous, including malignant disease $(2 \cdot 2 \%)$. The proportions of deaths due to these 
causes were not significantly different between the controls and the people with markers or those sent the questionnaire.

\section{CHANGE IN THYROID FUNCTION}

\section{Antibodies}

Sera were available from all but four of the 372 people seen throughout the four-year follow-up. Thirty men and 97 women were initially positive for thyroid (predominantly microsomal) antibodies. Nine subjects were initially weakly positive for antibodies (five thyroglobulin and four microsomal); this was not confirmed on retesting the stored sera, and the results remained negative at two-year and fouryear follow-up. These nine may be regarded as originally giving falsepositive results.

Three women were strongly positive for microsomal antibodies groups studied were significantly lower at the two-year follow-up than basally and at four-year follow-up. This interassay variation was eliminated when all the avilable sera from each subject were retested in the same assay at the end of the follow-up, although the reassay values tended to be lower than the original values (table III).

Mean TSH concentrations in the controls did not vary significantly over the four years when retested, and only $5 \%$ of the women and none of the men developed a concentration above $6 \mathrm{mU} / \mathrm{l}$. Mean concentrations in the 67 women and 20 men who initially had only antibodies as a marker were significantly higher than those in the controls throughout the study but remained in the normal range, and only $10(12 \%)$ of these subjects developed a concentration above $6 \mathrm{mU} / 1$ over the four years. Mean concentrations in the $27 \mathrm{wrmen}$ and nine men who initially had raised concentrations but no antibodies tended to regress to the mean over four years, although this decline was not significant when the samples were reassayed. The concentrations in this group ranged from 6 to $10 \mathrm{mU} / 1$ initially and rose above

TABLE III-Mean TSH concentrations ( $m U / l)$ basally and at two-year and four-year follow-up, comparing values obtained originally and when samples were reassayed at end of study*

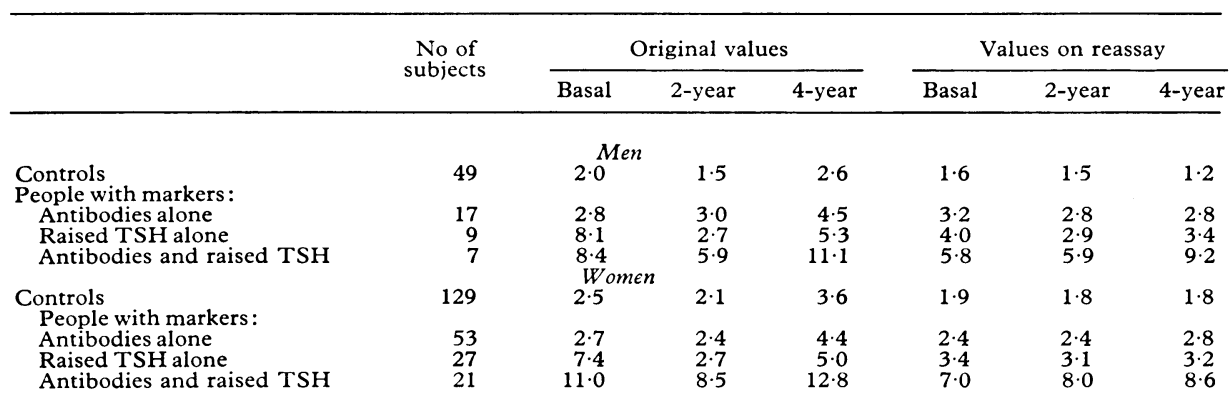
* Subjects who became overtly hypothyroid and were treated during the study and those for whom samples were missing are excluded.

TABLE IV-Mean free thyroxine index basally and at two-year and four-year follow-up*

\begin{tabular}{|c|c|c|c|c|c|c|c|c|}
\hline & \multicolumn{4}{|c|}{ Men } & \multicolumn{4}{|c|}{ Women } \\
\hline & \multirow{2}{*}{$\begin{array}{c}\text { No of } \\
\text { subjects }\end{array}$} & \multicolumn{3}{|c|}{ Free thyroxine index } & \multirow{2}{*}{$\begin{array}{c}\text { No of } \\
\text { subjects }\end{array}$} & \multicolumn{3}{|c|}{ Free thyroxine index } \\
\hline & & Basal & 2-year & 4-year & & Basal & 2-year & 4-year \\
\hline $\begin{array}{l}\text { Controls } \\
\text { People with markers: }\end{array}$ & 51 & 94 & 112 & 97 & 127 & 101 & 112 & 103 \\
\hline $\begin{array}{l}\text { People with markers: } \\
\text { Antibodies alone } \\
\text { Raised TSH alone } \\
\text { Antibodies and raised TSH }\end{array}$ & $\begin{array}{r}20 \\
9 \\
10\end{array}$ & $\begin{array}{r}97 \\
100 \\
79\end{array}$ & $\begin{array}{r}104 \\
114 \\
90\end{array}$ & $\begin{array}{l}96 \\
88 \\
82\end{array}$ & $\begin{array}{l}53 \\
20 \\
20\end{array}$ & $\begin{array}{r}100 \\
89 \\
84\end{array}$ & $\begin{array}{r}103 \\
110 \\
76\end{array}$ & $\begin{array}{l}96 \\
96 \\
71\end{array}$ \\
\hline
\end{tabular}

*Subjects who became overtly hypothyroid and were treated during the study and those for whom samples were missing are excluded.

(one of whom was also strongly positive for thyroglobulin antibodies), and this was confirmed on retesting the original sera, but antibodies were absent at two-year and four-year follow-up. Antibodies thus disappeared from three out of 88 women over four years.

Sixty men ( 51 controls and nine subjects with raised initial TSH concentrations) and 185 women (158 controls and 27 subjects with raised initial TSH concentrations) had no antibodies initially. Ten women who were thought to have no antibodies when first tested but were positive for microsomal antibodies after two and four years were found to have been positive for antibodies when the original sera were retested; they may be regarded as originally giving false-negative results. Antibodies developed in 16 women (13 controls and three subjects with raised initial TSH concentrations) who had no antibodies originally, confirmed on retesting. Antibodies thus appeared in 16 out of 175 women over four years. The antibody state of the men did not change throughout the study.

\section{$T S H$}

Sera for assay of TSH concentrations were available from 353 of the 372 people seen throughout the follow-up. Samples were obtained from 190 controls (139 women and 51 men) and 163 subjects with markers (124 women and $39 \mathrm{men})$. TSH concentrations in all the this subsequently in only one subject. Mean concentrations in the 30 women and 10 men who initially had antibodies and raised concentrations were significantly higher than those in the people who initially had only one marker. Concentrations remained raised in this group throughout the study (excluding those who developed overt hypothyroidism, whose concentration fell in response to treatment-see below). The range of initial concentrations in this group was 6-24 $\mathrm{mU} / 1$; the concentration fell in only one subject, in whom it had initially teen about $6 \mathrm{mU} / 1$.

\section{Circulating thyroid hormone concentrations}

Mean free thyroxine index was lowest at all stages in the people with both markers (table IV). Mean values were higher in all subjects at two-year follow-up than originally or at the four-year follow-up, except in women with both markers, in whom the index fell steadily. The fall in the index in this group was significant, whereas fluctuations in the controls and other marker groups may be explained by normal interassay variation.

Mean triiodothyronine concentrations were not significantly different between controls and any marker group either initially or at two- and four-year follow-up. 


\section{Thyrotoxicosis}

Thyrotoxicosis developed in two women, both controls, who developed clinical as well as biochemical features of hyperthyroidism. Five other women, who did not have clinical evidence of hyperthyroidism, showed borderline increases in serum thyroxine concentrations and free thyroxine index, which were not confirmed on retesting.

\section{DEVELOPMENT OF OVERT HYPOTHYROIDISM}

Seven women and one man became overtly hypothyroid during the study, four in the first and four in the second two years. All eight had thyroid antibodies and seven raised TSH concentrations when first seen. All developed symptoms and signs consistent with clinical hypothyroidism. Their TSH concentrations rose and thyroxine concentrations fell before treatment with thyroxine (figure), which led to clinical improvement and return of these two concentrations to the normal range. Three other women, who had antibodies and raised graphic abnormalities persisted (four of whom had evidence of ischaemic heart disease); and the concentrations remained raised in three, whose electrocardiograms returned to normal.

\section{LIPID CONCENTRATIONS}

Mean fasting cholesterol and triglyceride concentrations were not significantly different between controls and the marker group at all stages of follow-up. Mean $( \pm S D)$ basal cholesterol concentrations in the women with both markers of thyroid disease were higher than those in the controls $(6 \cdot 9+1 \cdot 20 v 6 \cdot 3+1 \cdot 14 \mathrm{mmol} / 1 ; 267+46 v 244+44 \mathrm{mg} /$ $100 \mathrm{ml}$ ), and this difference persisted but did not increase during the follow-up $(6.7 \pm 1.24 v 6.1+1.19 \mathrm{mmol} / 1(259+48 v 236 \pm 46 \mathrm{mg} /$ $100 \mathrm{ml}$ ) after four years). Mean cholesterol concentrations in the women with only one marker were not significantly different from those in the controls at any stage. Among the eight people who developed overt hypothyroidism four originally had cholesterol concentrations below and four above the mean in the controls.
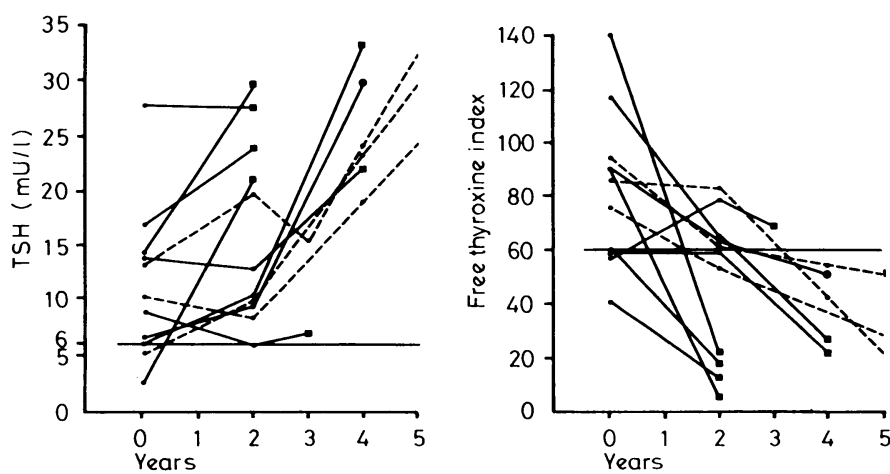

TSH concentrations and free thyroxine index in seven women (and one man ( - ) who developed overt hypothyroidism during the study and three women (- - - ) who subsequently developed clinical as well as biochemical evidence of hypothyroidism.

TSH concentrations initially $(6,10$, and $14 \mathrm{mU} / 1$ respectively), also showed a progressive rise in TSH concentrations and fall in thyroxine concentrations to below the normal range but were not recognised as clinically hypothyroid at the four-year follow-up. It was predicted that they would soon become overtly hypothyroid, and this occurred in all three within the following year. These three subjects although biochemically hypothyroid were not included in the subsequent analysis of the incidence of overt hypothyroidism.

One woman of the 67 who initially had antibodies but normal TSH concentrations became overtly hypothyroid during the four years. None of the controls and none of the subjects who initially had raised TSH concentrations but no antibodies became overtly hypothyroid.

Six of the 30 women and one of the 10 men who initially had both raised TSH concentrations and thyroid antibodies became overtly hypothyroid during four years.

None of the subjects sent the questionnaire after four years had developed overt thyroid disease; thus, on the assumption that those identified in the group with markers represent all the cases of overt hypothyroidism occurring in the original sample of the population (1285 men, 1494 women) the annual incidence of overt hypothyroidism is between 1 and $2 / 1000$ women and about $1 / 5000$ men.

\section{ELECTROCARDIOGRAPHIC CHANGES}

An association between minor electrocardiographic changes and raised TSH concentrations but not the presence of antibodies was found in women in the original survey. This association was present in women selected for follow-up but disappeared over the four years. Fifteen women initially had raised TSH concentrations and minor electrocardiographic changes, but both of these returned to normal in six (four of whom were treated with thyroxine); the TSH concentration fell spontaneously to normal in six others, whose electrocardio-

\section{Discussion}

By itself a raised TSH concentration did not appear to have any predictive value for the development of overt hypothyroidism over four years. Possibly this was because most of the concentrations were only slightly increased-that is, between 6 and $10 \mathrm{mU} / 1$. The mean and range of TSH concentrations were considerably higher in subjects in whom $\mathrm{TSH}$ concentrations were raised and antibodies present: $5 \%$ of these women developed overt hypothyroidism a year. In a highly selected group of subjects with autoimmune thyroiditis whose initial TSH concentrations were above $19 \mathrm{mU} / 1$ Gordin and Lamberg ${ }^{17}$ showed that overt hypothyroidism developed at a rate of roughly $10 \%$ per annum over three years. Thus the higher the TSH concentration the greater the likelihood of developing overt hypothyroidism. We were unable to show any relation between the degree of increase of $\mathrm{TSH}$ concentrations and increasing titre of antibodies.

Interassay variation is considerable in all radioimmunoassays and was a major handicap in our evaluation of borderline values, most of which fell at two years but were higher at four years. Repeat assays of all the stored samples after four years eliminated interassay variation but did not exclude the effect of deterioration of the earlier samples because of longer storage. All samples were taken between 9 and 11 am so that diurnal variation was unlikely to account for the observed variation, and people were seen close to the anniversary of their original visit, so that seasonal variation was not a factor. Nevertheless, the mild fluctuations in TSH values might have been spontaneous, while the mean free thyroxine index was higher at two years than basally or at four years. In practical terms, in the absence of any evidence of underlying autoimmune thyroiditis mildly raised TSH concentrations are of doubtful clinical importance and should be rechecked.

Antibodies were initially scored as present at very low titresthat is, $1 / 20$ for thyroglobulin, $1 / 10$ for cytoplasmic immunofluorescence, and $1 / 100$ for microsomal haemagglutination. Although microsomal haemagglutination occurred in over $80 \%$ of subjects in whom results of immunofluorescence testing were positive, ${ }^{14}$ perhaps not surprisingly up to $5 \%$ of tests yielded false-positive or false-negative results. Thyroglobulin titres of $1 / 40$ and microsomal titres of 1/200 or more disappeared genuinely from only three subjects. It was to be expected that antibodies would appear spontaneously in some women in the middle age range, and our annual incidence of $2 \%$ is consistent with the known rapid rise in the prevalence of antibodies in women aged over 45. Mean microsomal antibody titres tended to increase (by one dilution-that is, from $1 / 400$ to $1 / 800$ ) over the four years in those in whom these antibodies were present at the beginning of the study.

The meaning of minor electrocardiographic changes remains 
open to question. Minor ST and T-wave changes have some prognostic importance for ischaemic heart disease ${ }^{1819}$ but are evanescent. In the original survey ${ }^{20}$ minor electrocardiographic changes showed a weak association with raised TSH concentrations, but this disappeared during follow-up. The proportion of deaths due to cardiovascular disease was not significantly different between controls and the marker groups. Thus there was no evidence of any association between ischaemic heart disease and symptomless autoimmune thyroiditis, ${ }^{21}$ but the numbers were small.

Mean fasting cholesterol and triglyceride concentrations were not significantly different between controls and subjects with only one marker. Although mean cholesterol concentrations were slightly higher in women with both markers, they were within the normal range, did not change during follow-up, and had no prognostic value in identifying those who developed overt hypothyroidism. There was thus no evidence to support the hypothesis that raised cholesterol concentrations indicate premyxoedema. ${ }^{22} 23$

\section{PREVENTION OF OVERT HYPOTHYROIDISM}

In our survey three women with unequivocal biochemical hypothyroidism were not detected clinically. Should people with antibodies and raised TSH concentrations be treated with thyroxine to prevent the development of overt hypothyroidism? The people in this study were not patients but randomly selected from a cross-section of the community. Before advocating widespread screening of adult women for raised $\mathrm{TSH}$ concentration and antibodies it is important to decide whether subjects having these should be treated. Arguments in favour of treatment are as follows: (a) overt hypothyroidism develops insidiously and may impair mental and physical function; (b) the incidence of overt hypothyroidism in women with both markers is $5 \%$ per annum. Moreover, this is cumulative, so that after four years $20 \%$ are affected and after 10 years half might have overt hypothyroidism; (c) treatment is simple, cheap, and effective; and $(d)$ women may not realise they were functioning below normal until they realise how much better they feel with treatment.

Arguments against treatment of asymptomatic individuals with both markers include: (a) many women live their normal span without ever developing clinical evidence of thyroid disorder; (b) treatment may prevent one in 20 developing overt hypothyroidism in one year, but 19 will be treated unnecessarily; (c) thyroxine may be dangerous particularly in exacerbating ischaemic heart disease; $(d)$ some of the cases of overt hypothyroidism will be recognised anyway; and (e) some people with overt hypothyroidism fail to take their thyroxine regularly, and hence probably those women who are asymptomatic and feel no benefit from treatment may default.

If the data from Whickham are applicable to the population of Great Britain with roughly 20 million adult women, 5\% (that is, one million) would have both raised $\mathrm{TSH}$ concentrations and thyroid antibodies. Of them, $5 \%$ per annum (that is, 50000 ) might develop or be prevented from developing overt hypothyroidism. The logistics of setting up a screening programme for all adult women would be considerable. Higher returns for the investment would be obtained from screening, say, only women over the age of 45 . The cost effectiveness of such a programme would depend on the balance between its costs and the cost of the morbidity of untreated hypothyroidism, which is much more difficult to determine.

Until now we have not advocated treatment for asymptomatic people found to have thyroid antibodies or raised TSH concentrations on the grounds that the natural course was not known and that the benefits of treatment might not outweigh the disadvantages. Now our view has been modified by the findings of the present study. It seems reasonable to recommend thyroxine treatment for women presenting to their doctor who are found to have both raised TSH concentrations and antibodies (but neither alone) provided there is no hazard-for example, exacerbating ischaemic heart disease. Nevertheless, we are not advocating a widespread screening programme for autoimmune thyroditis in the whole population: this must await a precise economic evaluation. On the other hand, it may be worth while screening high-risk groups such as postmenopausal women attending a clinic for any reason or in hospital wards (particularly geriatric) and women attending diabetic clinics or thyroid clinics who have had destructive treatment of the thyroid by surgery or radioiodine.

We thank the people of Whickham for participating in the study; the general practitioners of Whickham and Dunston and their staff for their co-operation; the staff of Whickham Cottage Hospital and Dunston Health Centre for their hospitality; and the secretarial and laboratory staff of the departments of medicine and clinical biochemistry, Royal Victoria Infirmary, and the department of haematology, Newcastle General Hospital, for their collaboration.

Financial support was gratefully received from the Department of Health and Social Security; the League of Friends of the Royal Victoria Infirmary, Newcastle upon Tyne; the Radiochemical Centre, Amersham; Mallinkrodt Limited; Glaxo Limited; and Roche Products Limited.

Correspondence should be addressed to Dr W M G Tunbridge.

\section{References}

1 Tunbridge WMG, Evered DC, Hall R, et al. The spectrum of thyroid disease in a community: the Whickham survey. Clin Endocrinol 1977;7: 481-93.

${ }^{2}$ Gordin A, Heinonen OP, Saarinen P, Lamberg BA. Serum thyrotrophin in symptomless autoimmune thyroiditis. Lancet $1972 ; \mathrm{i}: 551-4$.

${ }^{3}$ Gordin A, Maatela J, Miettenen A, Tuila H, Lamberg BA. Serum thyrotrophin and circulating thyroglobulin and thyroid microsomal antibodies in a Finnish population. Acta Endocrinol 1979;90:33-42.

${ }^{4}$ Goudie RB, Anderson JR, Gray KG. Complement fixing antithyroid antibodies in hospital patients with asymptomatic thyroid lesions. fournal of Pathology and Bacteriology 1959;77:389-400.

${ }^{5}$ Bastenie PA, Neve P, Bonnyns M, Vanhaelst L, Chailly $M$. Clinical and pathological significance of atrophic thyroiditis. Lancet $1967 ; \mathrm{i}: 915-9$.

${ }_{6}$ Williams ED, Doniach I. The post mortem incidence of focal thyroiditis. Fournal of Pathology and Bacteriology 1962:83;255-64.

${ }^{7}$ Rose GA, Blackburn H. Cardiovascular survey methods. WHO Monogr Ser 1968;56.

8 Wright BM, Dore CF. A random-zero sphygmomanometer. Lancet 1970; i:337-8.

${ }^{9}$ Hall R, Amos J, Ormston BJ. Radioimmunoassay of human serum thyrotrophin. Br Med f $1971 ; \mathrm{i}: 582-5$.

${ }^{10}$ Hesch RD, Evered DC. Radioimmunoassay of triiodothyronine in unextracted human serum. Br Med F 1973; i :645-8.

${ }^{11}$ Clark F, Brown HJ. Evaluation of Thyopac-3 test in the in-vitro assessment of thyroid function. $\mathrm{Br}$ Med $\mathcal{F} 1970 ; \mathrm{i}: 713-5$.

${ }^{12}$ Fulthorpe AJ, Roitt IM, Doniach D, Couchman K. A stable sheep cell preparation for detecting thyroglobulin antibodies and its clinical applications. F Clin Pathol 1961 ;14:654-60.

13 Doniach D. Thyroid autoimmune disease. $\mathcal{F}$ Clin Pathol 1967 ;20:385-90.

14 Bird T, Stephenson J. Evaluation of a tanned red cell technique for thyroid microsomal antibodies. F Clin Pathol 1973;26:623-7.

15 Fletcher MJ. A colorimetric method for estimating serum triglycerides. Clin Chim Acta 1968;22:393-7.

${ }^{16}$ Nie N, Pent DH, Hull CH. Statistical package for the social sciences. London: McGraw Hill, 1970.

17 Gordin A, Lamberg BA. Natural course of symptomless autoimmune thyroiditis. Lancet 1975 ;ii:1234-8.

${ }^{18}$ Kannel WB, Gordon T, Castelli WP, Margolis JR. Electrocardiographic left ventricular hypertrophy and risk of coronary heart disease. Ann Intern Med 1970;72:813-22.

19 Rose G. Predicting coronary heart disease from minor symptoms and electrocardiographic findings. Brf Prev Soc Med 1971 ;25:94-6.

20 Tunbridge WMG, Evered DC, Hall R, et al. Lipid profiles and cardiovascular disease in the Whickham area with particular reference to thyroid failure. Clin Endocrinol 1977 ; 7:495-508.

21 Bastenie PA, Vanhaelst L, Bonnyns M, Neve P, Staquet M. Preclinical hypothyroidism: a risk factor for coronary heart disese. Lancet 1971 ; : 203-4.

22 Fowler PBS, Swale J. Premyxoedema and coronary artery disease. Lancet 1967 ;i:1077-9.

${ }^{23}$ Fowler PBS, Swale J, Andrews H. Hypercholesterolaemia in borderline hypothyroidism. Lancet $1970 ; \mathrm{ii}: 488-91$.

(Accepted 6 November 1980) 